\title{
Analysis and Prediction of Land Use/land Cover Changes and Driving Forces by Using GIS and Remote Sensing in the Coka Watershed, Southern Ethiopia
}

Tadele Buraka ( $\square$ tesfitade4@gmail.com )

Addis Ababa University College of Natural Sciences

Eyasu Elias

Addis Ababa University

Alemu Lelago

Wolaita Sodo University

\section{Research Article}

Keywords: environment, GIS analysis, landscape, watershed

Posted Date: September 9th, 2021

DOI: https://doi.org/10.21203/rs.3.rs-884581/v1

License: @ (1) This work is licensed under a Creative Commons Attribution 4.0 International License. Read Full License

Version of Record: A version of this preprint was published at Indian Journal Of Agricultural Research on March 30th, 2022. See the published version at https://doi.org/10.18805/IJARe.A-699. 


\section{Abstract}

Land use and land cover (LULC) is among fundamental environmental and ecological factors for monitoring, resource management, police making, planning and facilitating the development of strategies to balance conservation, development pressures, and conflicting uses. This study aimed at analyzing LULC changes that have occurred during 1988-2018 and its prediction for 2040-2060 period in Coka watershed, southern Ethiopia. LULC changes were analyzed using geographic information system and predicted by CA-Markov model. Cultivated and rural settlement land, bare land, built up area and water body have increased at an annual rate of 23.1, 2.2, 0.8 and 1.1 ha/year but forest land, bushland and grassland have decreased at an annual rate of 14.4, 4.1 and 8.7 ha/year, respectively. It is projected that cultivated and rural settlement land, bare land, built up area and water body will expand but forest land, grassland and bushland will decrease. Expansion of agriculture and deforestation showed increasing trend on both previous and predicted LULC changes with upcoming expansion of bare land and eucalyptus tree plantation due to major driving factor of population growth. This study highlights the need for well integrated landscape planning, reliable predictions for future LULC and to reduce the deterioration of environment.

\section{Introduction}

Land use and land cover (LULC) change is a non-linear dynamic transformation of one land use type to another where human activities influence the ecosystem (Kishtawal et al., 2010; Pielke et al., 2011). An intersection of natural and anthropogenic factors like climate changes, policy adjustments, population growth and decrease in productivity of land are among the major drivers for LULC changes (Dessie and Kleman, 2007; Meshesha et al., 2014, Nanda et al., 2014). World's landscape modification has been greatly affected by LULC changes (Lambin et al., 2011). Although the LULC changes vary greatly in intensity, degree and patterns across the regions, their ultimate outcome is the use and exploitation of natural resources to meet the increasing demands caused by the growing human population at the expense of the environment (Lambin and Meyfroidt, 2011; Meshesha et al., 2014; Wondie et al., 2011). Therefore, study in LULC change is the main concern of national and international research to prevent its negative impact from our environment and ecosystem services.

Some studies on LULC dynamics revealed that some land use types expanded the expense of others (Agidew and Singh, 2017; Efrem, 2010; Minta et al., 2018; Worku et al., 2016; Wubie, 2016). In most cases, at the expense of forest land. As reported by Temesgen et al. (2017), cultivated land and built up areas expanded at the expense of forest, bush and grass land during 1985-2015 periods in Andassa watershed, Ethiopia. On the other hand, drastic expansion of urban built-up area at the expense of cultivated land is reported in the northeastern and northern Ethiopia (Gebrelibanos and Assen, 2013; Kebrom and Hedlund, 2000). Land degradation caused by cultivated land expansion is a common feature of the landscape and predominant environmental degradation dynamics mainly in the rural parts of Ethiopia (Billi, 2015; CSA, 2018; Hurni et al., 2005; Nyssen et al., 2004).

According to Assefa and Bork (2016) and Wagesho (2014), grassland reduced due to rapid population growth and agricultural expansion around Chencha and Arba Minch areas of the southern Ethiopia. A similar result is reported by Yonas et al. (2013) that high degradation of grassland occurred following the government resettlement program in southwestern Ethiopia. The Ethiopian Biodiversity Institute report showed that forest land decreased by $27.5 \%$ during $1900-2013$ periods throughout in the country (EBI, 2014). Molla et al. (2010) confirmed that continuous removal of vegetation cover has occurred which was $70 \%$ of the forest land and significant proportions of bush land in the mountain landscape of Tara Gedam and adjacent agro-ecosystem over a period of 46 years in Ethiopia. According to several reports, the forest covered in Ethiopia approximately $40 \%$ of the land a century ago but now it has shrunken to only 3\% (Berry, 2003). On the other hand, an improvement in expansion of forest and shrub land cover in the Siemen Mountain National Park of Ethiopia has been reported by Menale et al. (2011).

LULC change is driven by multiple factors from environmental, economic and social dimensions in the ecosystem (Gong et al. 2015). Environmental degradation is caused by land use and land cover changes at a variety of spatial and temporal scales (Desalegn et al., 2014; Maitima et al., 2009; Temesgen et al., 2013). Expansion of cultivated land, built up areas and bare land at the expense of forest land, bush land and grass land have clearly shown the occurrence of environmental degradation, loss of biodiversity, disturbance of ecosystem and climatic change. Different researchers argue that LULC could be the reason for the reduction of the soil value by exposing the land to soil erosion, reducing the protection of soil and minimizing the productivity of soil in Ethiopia (Birhan and Assefa, 2018; Erkossa et al., 2015; Tsehaye and Mohammed, 2013). In addition, LULC change resulted soil sediments deposited in hydroelectric power reservoirs for example Aba-Samuel and Gilgel Gibe I (Devi et al., 2008), Koka (Hathaway, 2008), Tekeze (Welde, 2016) and Angereb Dam (Wolancho, 2012) has resulted in loss of hydroelectric power generation capacity in Ethiopia.

According to Getachew (2013) and Gerold (2012), LULC changes have been disturbing climatic conditions and hydrological regimes including increased peak flow for the wet months and decreased based flow of stream in the dry season in Angereb watershed and Hare watershed, Ethiopia. Moreover, it reduced infiltration and ground water recharge, increased runoff, decreased both surface and ground water 
flows (Bewket and Strek, 2005; Meyer et al., 1995; Narulita, 2012). Regarding socio-economic aspect, the negative effect of LULC change (environmental degradation) has been estimated the annual loss of GDP from the agriculture sector at 2.3\%-3\% (Berry, 2003; MoARD, 2010) and brought about out-migration of productive rural population (Wondwosen et al., 2018), in Ethiopia.

The above research findings indicate that formation of a given land cover results in a complex process in the environment and eco-system services. Data on LULC change and its cause and consequence on environments are very important for policy formulation, decision making and sustainable management. However, information on the regular monitoring and dynamics of LULC changes and their drivers are not adequately available for the current study area and its surroundings. No study conducted for LULC changes and its causes, consequences and impacts on environment for policy makers and researchers in the last long periods of years in and around Coka watershed. Thus, it has been difficult to manage the natural resources, monitor environmental changes and predict the future conditions of the landscape. This study has investigated and documented the spatio-temporal land use and land cover changes of study watershed to fulfill this gap. The aims of this study were to analyzing and evaluate the LULC changes and their driving forces which have occurred over the past three decades from 1988 to 2018 and predicting LULC changes for coming four decades from 2018 to 2060 in Coka watershed, southern Ethiopia.

\section{Materials And Methods}

\subsection{Description of the study area}

Coka Watershed is found at the geographic bounds of $7^{\circ} 12^{\prime} 10^{\prime \prime} \mathrm{N}-7^{\circ} 18^{\prime} 20^{\prime \prime} \mathrm{N}$ latitude and $37^{\circ} 31^{\prime} 0^{\prime \prime} \mathrm{E}-37^{\circ} 34^{\prime} 25^{\prime \prime} \mathrm{E}$ longitude in the administrative region of the southern nations and nationalities people region, Ethiopia (Fig. 1). The total area of the watershed is about 3731 ha. Its altitude ranges from 772 to 2524 m.a.s.l. with slope gradients varying between gently (2\%) and very steep (>60\%) (WoA, 2019).

The mean annual rainfall amount is in Coka watershed varying from the highest total annual $1727.8 \mathrm{~mm}$ in 1992 to the lowest total annual $932.7 \mathrm{~mm}$ in 2018 (Fig. 2). The mean annual minimum and maximum temperature of study area is $12.2^{\circ} \mathrm{C}$ and $26.3^{\circ} \mathrm{C}$, respectively (Fig. 2 ). The main rainy season is between June and September while the short rains fall between February and April. Coka watershed has bimodal rainfall distribution small (belg) and major (Kiremt). Rains in kiremt season are intensive which uses for crop production and causes soil erosion during this time at different parts in the study watershed. Most of the economic and food crops production take place during the kiremt season in Coka watershed. According to the traditional agro-climatic classification system of Ethiopia (MoA, 1998), the study watershed can be classified into kola or warm semiarid (500-1500/1800 m), woinadega or cool sub-humid (1500/1800-2300/2400 m) and dega or cool and humid (2300/2400-3200 m).

The study watershed drains into the Coka stream, forming a tributary of the Omo river that flows into L. Turkana, south of Ethiopia bordering with Kenya. Geologically, the area is covered by trap series volcanics of the tertiary period that are langely acidic rocks such as rhyolites, ignimbrites and trachites covering the basemen complex of the precamberian rocks (Elias, 2016). Moderate to deeper soils are found in the moderate to gentler slopes and shallower soils are found on steeper slopes in Coka watershed. According to Alemu and Tadele (2019), the soil type of the study watershed is Nitisol.

\subsection{The socioeconomic setting}

The total population of study watershed was 12493 in 1994, 14303 in 1998, 17486 in 2008 and 21,043 in 2018 (CSA, 2019 ). This shows that the population of study watershed has increased by $40.6 \%$ from 1994 to 2018 (Fig. 3). Suggesting, the presence of dramatic increment of population in the study watershed over the 30 years.

The farming system is dominated by mixed crop-livestock system which consists of intensive and continuous crop cultivation and animal husbandry. The main cultivated crops are maize (Zea mays L.), teff (Eragrostisteff Z.), sorghum (Sorghum bicolor L.), wheat (Triticum durum Desf.), barley and legumes such as haricot bean, fababean and pea. The homestead areas are largely planted in enset (Ensetteventricossum), coffee (Coffee Arabican) with undergrowth of root crops (sweet potato, cassava, ginger and yams). Traditionally, crop rotation had been one of the soil fertility maintenance methods but it is no more used in the study area due to shortages of farmland as a result of high population pressure.

\subsection{Data types and sources}

\subsubsection{Remote sensing (RS) data}

Land use and land cover changes over time were assessed using remote sensing data from satellite images (Landsat-5 TM for 1988 and 1998, Landsat-7 ETM+ for 2008 and Landsat-8 OLI-TIRS for 2018) with 30 m* 30 m spatial resolution and path/row of 169/55 were used as 
data sources for the LULC change analysis for the different periods. Landsat data was downloaded from open access U.S. Geological survey (USGS) Center for Earth Resources Observation and Science (EROS) (https://earthexplorer.usgs.gov/). ASTERGDEM with $30 \mathrm{~m}$ cell size was obtained from Aster Global Digital Elevation Map (http://gdex.cr.usgs.gov/gdex/). ASTERGDEM and local topographic maps (1:50000) were used to create digital elevation model (DEM) and this was used as input data for the topographic parameter analysis.

The years of analysis were selected by considering timeline of events at national and local levels such as policy changes on the land tenure in addition to years of quality and availability of Landsat images into consideration. The images were acquired in the same season to avoid the effect of seasonal variations and selected zero could satellite images due to avoid could effect. Feld visits, Google Earth image, historical aerial photo from Geological and map agency of Ethiopia and raw images were sources for ground sample points. Raw images through visual interpretation in combination with historical aerial photo, GPS points and Google Earth datasets were used to collect sample points for earlier reference years that are 1988, 1998 and 2008. Field visit, GPS points and Google Earth datasets were used to collect samples for the 2018 reference year. Reference points were collected for the study years and classified images from the corresponding Google Earth images which were collected using dry months (December and January) for clear images.

About 50-75 random ground points per land use class were collected for accuracy assessment and land use type classification. GPS points of major LULC classes, Kebele boundary and location of Tembaro district were recorded. All the datasets were projected to the Universal Transverse Mercator (UTM) map projection system zone $37 \mathrm{~N}$ and datum of World Geodetic System 84 (WGS84), ensuring consistency between datasets during analysis.

\subsubsection{Field data collection}

The major causes of LULC changes were explored by using key informant interviews (KII) and focus group discussions (FGD) with local communities from six kebeles. FGD members were selected considering age (age above 45), continuously living in the area for more than 35 years, willingness to participate in the interview and considered by local people as knowledgeable about the study area for the interviews. Each FGDs having eleven members (men and women) were conducted. Identification of key informants was assisted by the development agents (DAs) of agriculture such as Tembaro woreda Agricultural Development, Environmental protection, and Land Administration office workers. Key informants were interviewed which took about an hour with each individual.

\subsection{Data Analysis}

\subsubsection{Image classification and analysis}

The four Landsat images were performed to identify useful thematic information to investigate the LULC changes in Coka watershed. Preprocessing activities like geometric and radiometric corrections were applied before image classification. Sub-setting and layer stacking were performed before commencement of the actual classification. Moreover, all the acquired satellite images were enhanced using histogram equalization to improve image quality.

The hybrid classification technique was applied for satellite image classification which combines both unsupervised and supervised classification techniques. Lilles and Kiefer (2000) and Solomon et al. (2014) argue that the hybrid classification method is better than using either unsupervised or supervised classification techniques alone. Primarily, unsupervised classification was derived by using Iterative SelfOrganizing Data Analysis (ISODATA) clustering method as a reference points for gathering ground truth points. Using signature editor of unsupervised classes, a pixel based supervised classification with maximum likelihood classification (MLC) algorism was carried out using the ground truth points gathered from each LULC category. Researchers like Teferi et al. (2010), Temesgen et al. (2014) and Solomon et al. (2014) analyzed LULC data following the same procedures. Projection of LULC of Coka watershed for the periods 2040 and 2060 were done with Cellular Automata Markov (CA-Markov) model in TerrSet software. According to Wang et al. (2012) and Li et al. (2015), CA-Markov predicts not only the trend but also the spatial structure of different LULC categories. An ERDAS Imagine 2015, ArcGIS 10.5 and TerrSet software were used for image classification, mapping and prediction for future (2040 and 2060) land use, respectively.

\subsubsection{Accuracy assessment}

A minimum (50 points) and maximum (73 points) random ground points per class (367 total GPS points) were used for accuracy assessment in ERDAS Imagine 2015. The accuracy assessment points were independent from those used as training samples that were carried out by creating error matrix. The matrix compares information obtained by reference sites provided by classified image for a number of sample areas. Next, the classified images were compared with the reference images by means of error matrix. Various measures of accuracy assessment - producer accuracy, user accuracy, and overall accuracy and Kappa coefficient were performed. Overall accuracy (Congalton 2005) was calculated by Eq. 1 as: -

Page 4/19 
Overall $(O A)=\left(\frac{x}{y}\right) * 100$

Where, $\mathrm{OA}$ is overall accuracy, $\mathrm{X}$ is number of corrected values in the diagonals of the matrix, and $\mathrm{Y}$ is total number of values taken as a reference point. Kappa coefficient (Congalton, 1991) was calculated using Eq. 2: -

$K=\frac{N \sum_{i=1}^{r} x i i-\sum_{i=1}^{r}\left(x i+*^{*} x+i\right)}{N^{2}-\sum_{i=1}^{r}\left(x i+*^{*} x+i\right)}$

Where, $\mathrm{K}$ is Kappa coefficient, $\mathrm{r}$ is the number of rows in the matrix, $\mathrm{xii}$ is the number of observations in row $\mathrm{i}$ and column $\mathrm{i}$, $\mathrm{xi}+\mathrm{are}$ the marginal totals of row $\mathrm{i}, \mathrm{x}+\mathrm{i}$ are the marginal totals column $\mathrm{i}$, and $\mathrm{N}$ is the total number of observations.

Producer's accuracy is also the number of reference sites classified accurately divided by the total number of reference sites for that class and multiplied by 100 . The User's Accuracy is calculating by taking the total number of correct classifications for a particular class and dividing it by the row total and multiplied by 100 .

\subsubsection{LULC change analysis}

LULC changes were analyzed and evaluated for periods 1988-2018 and predicted from 2018 for 2040 and 2060 periods. Images of different reference years were first independently classified and evaluated for area coverage and then change detection processes were performed. Change analysis was conducted using post-classification image comparison techniques, which was used to minimize possible effects of atmospheric variations and sensor differences with spatial resolution. LULC change detection was made using Eqs. 3 and 4 :

LULC change $(\%)=\frac{\mathrm{X}-\mathrm{Y}}{\mathrm{Y}} * 100$

Rate of LULC change (ha/year) $=\frac{X-Y}{Z}$

Where, $\mathrm{X}$ is area of LULC (ha) in time $2, \mathrm{Y}$ is area of LULC (ha) in time $1, \mathrm{Z}$ is time interval between $\mathrm{X}$ and $\mathrm{Y}$ in years.

In addition, change detection matrix of 'from-to' was derived to show LULC class changes during the 30-year periods (1988-2018) and also for projected 2040 and 2060 classified maps. The description provided in each land use and land cover category is derived from FAO (2010) report (Table 1).

Table 1

Description of land use and land cover classes in Coka watershed.

\begin{tabular}{|lll|}
\hline No. & Land use types & Description \\
\hline 1 & $\begin{array}{l}\text { Cultivated \& Rural settlement land } \\
\text { (CL\&RS) }\end{array}$ & $\begin{array}{l}\text { This category includes areas currently under crop, fallow land under preparation and } \\
\text { scattered rural settlements }\end{array}$ \\
\hline 2 & Bare land & Land surface without vegetation cover, or with rocky land. \\
\hline 3 & Built up area & Urban housing area (Mudulla Town \& Siemen Ambukuna kebele center expansion) \\
\hline 4 & Bush/shrub land & Land covered by small trees, bushes/shrubs \\
\hline 6 & Forest land & Land covered by grass with scattered shrubs \\
\hline 7 & Water body & Area dominated by high and dense natural and plantation forest \\
\hline
\end{tabular}

\section{Result And Discussion}

\subsection{Land use and land cover (LULC) change Trends and their conversion matrix}

Analysis of LULC patterns and the spatial distribution in the study watershed are presented in Tables 2 and 3 and Fig. 4.

\section{Cultivated land and Rural settlement area (CL and RS)}


Results show that cultivated land and Rural settlement areas have expanded from 742 ha (19.9\%) in 1988, to 1405 ha (37.7\%) in 1998, to 1423 ha (38.1\%) in 2008 and 1435 ha (38.5\%) in 2018 (Fig. 4; Table 2). The rate of change between 1988-1998, 1998-2008, 2008-2018 and also overall 1988-2018 periods, increased by $89.4,1.3,0.8$ and $93.4 \%$, respectively. The corresponding rates of increment for these study periods were $66.3,1.8,1.2$ and 23.1 ha/year, respectively (Table 2 ).

Table 3 shows that during 1988-2018 periods, 333, 224 and 550 ha of CL \& RS were gained from forest land, bush land and grassland, respectively. In this period, the highest gain was observed in CL and RS area 1107 ha (38.3\%) of which the highest area was from grassland 550 ha (49.7\%) followed by forest land 333 ha (30.1\%). It indicates that it might be occurred the scarcity of grass land for live stocks and cutting more trees for fuel and construction materials which could associate with overgrazing and deforestation that may lead to environmental degradation in the study watershed. In reverse, 329, 27, 39, 8 and 11 ha of CL and RS area were transformed to forest land, bush land, grass land, built up area and bare land, respectively and the total loss from CL and RS to other land types was 414 ha (14.3\%). Majority of CL and RS was converted to forest land 329 ha (79.5\%) followed by grass land 39 ha (9.4\%) during 1988-2018 (Table 3). This revealed that CL and RS area used for afforestation at the specified periods in the study watershed including majority area for eucalyptus trees.

From these findings, CL and RS is the dominant LULC type with a consistent increase at the expense of other LULCs in the catchment even though its growth was very slow during 1998-2008 and 2008-2018 (Table 2). In these periods, a regional resettlement programme occurred between1998-2005 for seven continuous years that framers from densely populated highland areas including this watershed moved to different other less populated lowland areas in southern Ethiopia. This government resettlement police implementation might have slowed down the land conversion in the second and third periods. Also the rest land may not be suitable for farming system due to landscape position. The rapid expansion of CL and RS was during 1988-1998 periods leaping from 19.9-37.7\% which is almost 50\% increment. According to FGD and $\mathrm{KI}$ interview the driving force for expansion of CL and RS was associated to an increment of population size demanding for food, construction and fuel production. Additionally, they said that the study watershed community faced food insecurity problems for long periods of years due to low crop productivity and environmental impact of eucalyptus trees expansion. Environmental impact of eucalyptus tree is negatively known as climate change due to its releasing halophytic chemicals and positively as income source for household farmers. The population in study area was increased by 59.4\% from 1994 to 2018 (CSA, 2019 , Fig. 3). It might be related to the 1991 change of government that resulted in the disbanding of the dergue army many of whom returned to their villages and given farm lands in the study watershed. Expansion of cultivated land may lead to degrading environment in one or other ways because expansion of agricultural activities could be associated with soil erosion, biodiversity loss, deforestation, climate change and hydrological disturbance. For example, when cultivated land increased extensively without appropriate management, nitrogen and phosphorus fertilizers unused by plants could be taken by runoff to water bodies which degrading water quality by eutrophication.

\section{Forest Land}

The forest area reduced from $34.6 \%$ in 1988 to $21.2 \%$ in 1998 and from $24.6 \%$ in 2008 to $23.0 \%$ in 2018 , with annual diminishing rate of 49.9, 5.8 and 14.4 ha/year during 1988-1998, 2008-2018 and overall 1988-2018 periods, respectively (Fig. 4; Table 2). Conversely, forest land increased from $21.2 \%$ in 1998 to $24.6 \%$ in 2008 with the increasing rate 12.5 ha/year between 1998-2008 (Table 2).

In Table 3, areas of forest land were transformed from bush land (104 ha), CL and RS (329 ha) and grassland (183 ha). Forest land gained much land from CL and RS (53.4\%) followed by grass land (29.7\%) and the total gain of forest land is 616 ha (21.3\%). This indicates that the increasing trend during 1998-2008 in forest land is associated with the adoption of sustainable land management (SLM) approach based on the participatory watershed rehabilitation scheme of the government that went to operation between 2002-2008 periods and mainly due to the expansion of Eucalyptus plantations in the study watershed. Divergently, 473, 333, 197, 6, 20 and 19 ha of forest land were converted to bush land, CL and RS, grassland, built up area, bare land and water body, respectively (Table 3). In these periods, the highest loss of forest land was observed in the study watershed which was 1048 ha (36.2\%), which is a large reduction that can significantly contribute to eco-environment degradation. FGD and KI interview made clear that this reduction of forest land due to expansion of cultivated land for food production and high deforestation occurred for fuel, charcoal and construction. Whereas, a simultaneous shrinkage was observed in the area of forest land, even though considerable area of land added to it from different land categories. This indicates that Coka watershed forest land is under considerable pressure due to a rapidly increasing population, expanding agricultural activities and increasing deforestation. 
Table 2

Summary of the classified LULC and their changes during 1988-2018 in Coka watershed.

\begin{tabular}{|c|c|c|c|c|c|c|c|c|c|c|c|c|c|c|c|c|}
\hline \multirow{3}{*}{$\begin{array}{l}\text { LULC } \\
\text { Types }\end{array}$} & \multicolumn{8}{|c|}{ LULC area coverage in $(\mathrm{Ha})$ and $(\%)$ during 1988-2018 } & \multicolumn{8}{|c|}{ LULC change in (Ha) and $(\%)$ during 1988-2018 } \\
\hline & \multicolumn{2}{|l|}{1988} & \multicolumn{2}{|l|}{1998} & \multicolumn{2}{|l|}{2008} & \multicolumn{2}{|l|}{2018} & \multicolumn{2}{|c|}{$1988-1998$} & \multicolumn{2}{|c|}{ 1998-2008 } & \multicolumn{2}{|c|}{$\begin{array}{l}2008- \\
2018\end{array}$} & \multicolumn{2}{|c|}{$1988-2018$} \\
\hline & $\mathrm{Ha}$ & $\%$ & $\mathrm{Ha}$ & $\%$ & $\mathrm{Ha}$ & $\%$ & $\mathrm{Ha}$ & $\%$ & $\mathrm{Ha}$ & $\%$ & $\mathrm{Ha}$ & $\%$ & $\mathrm{Ha}$ & $\%$ & $\mathrm{Ha}$ & $\%$ \\
\hline $\begin{array}{l}\text { Forest } \\
\text { land }\end{array}$ & 1291 & 34.6 & 792 & 21.2 & 917 & 24.6 & 859 & 23 & -49.9 & -38.7 & 12.5 & 15.8 & -5.8 & -6.3 & -14.4 & -33.5 \\
\hline $\begin{array}{l}\text { Bush } \\
\text { land }\end{array}$ & 807 & 21.6 & 956 & 25.6 & 750 & 20.1 & 685 & 18.3 & 14.9 & 18.5 & -20.6 & -21.5 & -6.5 & -8.7 & -4.1 & -15.1 \\
\hline $\begin{array}{l}\text { CL \& } \\
\mathrm{RS}\end{array}$ & 742 & 19.9 & 1405 & 37.7 & 1423 & 38.1 & 1435 & 38.5 & 66.3 & 89.4 & 1.8 & 1.3 & 1.2 & 0.8 & 23.1 & 93.4 \\
\hline $\begin{array}{l}\text { Grass } \\
\text { land }\end{array}$ & 891 & 23.9 & 578 & 15.5 & 641 & 17.2 & 631 & 16.9 & -31.3 & -35.1 & 6.3 & 10.9 & -1 & -1.6 & -8.7 & -29.2 \\
\hline $\begin{array}{l}\text { Built } \\
\text { up }\end{array}$ & 0 & 0 & 0 & 0 & 0 & 0 & 23 & 0.6 & 0 & 0 & 0 & 0 & 2.3 & & 0.8 & \\
\hline $\begin{array}{l}\text { Bare } \\
\text { land }\end{array}$ & 0 & 0 & 0 & 0 & 0 & 0 & 66 & 1.8 & 0 & 0 & 0 & 0 & 6.6 & & 2.2 & \\
\hline $\begin{array}{l}\text { Water } \\
\text { body }\end{array}$ & 0 & 0 & 0 & 0 & 0 & 0 & 32 & 0.9 & 0 & 0 & 0 & 0 & 3.2 & & 1.1 & \\
\hline Total & 3731 & 100 & 3731 & 100 & 3731 & 100 & 3731 & 100 & $A$ & & B & & C & & $D$ & \\
\hline
\end{tabular}

\section{Bush Land}

The area of bush land increased from $21.6 \%$ in 1988 to $25.6 \%$ in 1998 but diminished from $25.6 \%$ in 1998 to $20.1 \%$ in 2008 and to $18.5 \%$ in 2018 (Fig. 4; Table 2). The rate of change was increased by 14.9 ha/year during 1988 - 1998 but decreased by 20.6, 6.5, and 4.1 ha/year during 1998-2008, 2008-2018 and 1988-2018, respectively (Table 2).

During 1988-2018 (Table 3), bush land expanded in expense of CL \& RS (27 ha), grassland (22 ha) \& forest land (473 ha) and the major gain was from forest land (90.6\%) with total gain of 522 ha (18.0\%). This reveals that conversion of more forest land to bush land could be associated with $\mathrm{CO}_{2}$ emission which might lead to climate change in the study watershed. In the same periods, 104, 224, 290, 3, 14, and 9 ha of bush land were converted to forest land, CL and RS, grassland, built up area, bare land, and water body, respectively. The highest bush land converted was to grass land (45\%) followed by cultivated land (34.8\%) with total loss of 644 ha (22.3\%) during the mentioned period (Table 3). The result shows that transformation of more bush land to grass land is one kind of environmental degradation which may come from overgrazing. According to FGD and KI interview the reduction of bush land was linked to an increment of number of animals and due to high demand of grazing area and expansion of CL \& RS in Coka watershed.

\section{Grassland}

The grassland area coverage of the watershed was $23.9 \%$ in 1988, 15.5\% in 1998, 17.2\% in 2008 and $16.9 \%$ in 2018 (Fig. 4; Table 2). During 1988-1998, 2008-2018 and 1988-2018 periods, grass land decreased by 31.3, 1.0 and 8.7 ha/year, respectively.

Generally, grassland gained from forest land (197 ha), bush land (290 ha) and CL \& RS (39 ha) during 1988-2018 periods (Table 3). The highest gain occurred was from bush land 290 ha (55.1\%) followed by forest land 197 ha (37.5\%) whose total gain is 526 ha (18.2) in the same periods. This showed that it increased by $6.3 \mathrm{ha} /$ year between 1998-2008 period due to clearing forest land and bush land for animal grazing (Table 3). In reverse, grassland converted to forest land (183 ha), bush land (22), CL and RS (550 ha), built up area (6 ha), bare land (21 ha) and water body (4 ha). The largest area of grassland 550 ha (70\%) transformed to CL \& RS followed by forest land 183 ha (23.3\%) and the total loss from the grass land is 786 ha (27.2\%) during 1988-2018 periods. This result showed that more grassland used for agricultural activities during over all periods (1988-2018) that might be related to increasing population size bearing expansion of CL and RS in the study area. FGD and local experts confirmed that the major driving force for decrement of grassland is expansion of agricultural activities which come from demand of food production in study watershed.

\section{Bare Land}


The area occupied by bare land was 66 ha (1.8\%) in 2018 (Fig. 4; Table 2). Its rate of increment during 2008-2018 and overall 1988-2018 periods was 6.6 ha/year and 2.2 ha/year, respectively (Table 2). The 1988, 1998 and 2008 LULC analysis divulges that bare land was not occurred in the Coka watershed.

In Table 3 (1988-2018 periods), bare land transformed from forest land (20 ha), bush land (14 ha), cultivated land (11 ha) and grassland (21 ha). Bare land gains the highest amount of land from grass land (32\%) with total gain of 66 ha (2.3\%). As FGD and KI interview put the reason of bare land expansion at third period was mismanagement of LULCs systems which results the degradation of cultivated land, forest land and grassland which could be associated with depletion of fertile land, loss of biological and economic productivity, soil erosion, habitat fragmentation and reduced ecosystem services in the study area.

\section{Built up Area}

The 1988, 1998 and 2008 LULC analysis reveals that the study watershed was not used by built up areas within the Tembaro woreda Mudulla Twon and Semene ambukuna kebele center (Fig.; Table 2). Built up area expanded 23 ha $(0.6 \%)$ in 2018. Its rate of increment during 2008-2018 and 1988-2018 periods, 2.3 ha/year and 0.8 ha/year, respectively (Table 2).

As indicated in Table 3 (1988-2018 periods), built up area was converted from forest land ( 6 ha), bush land ( 3 ha), cultivated land ( 8 ha) and grassland (6 ha). In the same period the least gain was observed in built up area $23 \mathrm{ha}(0.8 \%)$ and which the highest conversion from cultivated land $(34.8 \%)$ and the total gain of built up area is 23 ha $(0.8 \%)$ (Table 3$)$. The expansion of built up area was occurred in the expense of cultivated land, forest land, bush land and grass land. As indicated in Table, 33 (49.3\%) of farmers and local experts involved in FGD and KII elucidated that major cause for the expansion of built up area due to increment of land price, cutting more forest for construction and migration of people from rural to mudula town some land use types converted from cultivated land, grass land and bush land to built up area from Coka watershed in the north-east side of mudula town. This finding shows that the occurrence of expansion of urbanization toward the study watershed which may lead to habitat fragmentation and loss of natural resources which may provide remarkable wastes and causes environmental pollution for surrounding areas.

\section{Water Body}

The area coverage of water body was 32 ha (0.9\%) in 2018 (Fig. 4; Table 2). Its rate of increment during 2008-2018 and 1988-2018 periods $3.2 \mathrm{ha} /$ year and $1.1 \mathrm{ha} /$ year, respectively (Table 2). The 1988, 1998 and 2008 LULC analysis divulges that the back flow of gilgel gibe 3 dam water was not happened in the Coka watershed.

During 1988-2018 periods, water body was gained from bush (9 ha), grassland (3 ha) and forest land (19 ha) (Table 3). This result indicates that expansion of water body was occurred in the expense of cultivated land, forest land, bush land and grass land at the out let of Coka watershed. FGD and KI interview confirmed that the water body was increased during this period because of back flow of Gilgal gibe 3 dam accumulations at the bottom (outlet point) part of the study watershed. 
Table 3

LULC change matrix, net gain and net loss during 1988-2018 in Coka watershed

\begin{tabular}{|c|c|c|c|c|c|c|c|c|c|c|}
\hline \multirow{2}{*}{$\begin{array}{l}\text { Year } 1 \\
\text { (1988) }\end{array}$} & \multicolumn{7}{|c|}{ LULC types in Coka watershed in Year 2 (2018) } & \multirow{2}{*}{$\begin{array}{l}\text { Year1 } \\
\text { Total } \\
(\mathrm{Ha})\end{array}$} & \multirow{2}{*}{$\begin{array}{l}\text { Loss in1988 } \\
(\mathrm{Ha})\end{array}$} & \multirow{2}{*}{$\begin{array}{l}\text { Loss } \\
\text { in1988 } \\
(\%)\end{array}$} \\
\hline & $\begin{array}{l}\text { Forest } \\
\text { land }\end{array}$ & $\begin{array}{l}\text { Bush } \\
\text { land }\end{array}$ & $\begin{array}{l}\text { CL \& } \\
\text { RS }\end{array}$ & $\begin{array}{l}\text { Grass } \\
\text { land }\end{array}$ & $\begin{array}{l}\text { Built } \\
\text { up }\end{array}$ & $\begin{array}{l}\text { Bare } \\
\text { land }\end{array}$ & $\begin{array}{l}\text { Water } \\
\text { body }\end{array}$ & & & \\
\hline Forest land & 243 & 473 & 333 & 197 & 6 & 20 & 19 & 1291 & 1048 & 36.2 \\
\hline Bush land & 104 & 163 & 224 & 290 & 3 & 14 & 9 & 807 & 644 & 22.3 \\
\hline CL \& RS & 329 & 27 & 328 & 39 & 8 & 11 & 0 & 742 & 414 & 14.3 \\
\hline Grass land & 183 & 22 & 550 & 105 & 6 & 21 & 4 & 891 & 786 & 27.2 \\
\hline Built up area & 0 & 0 & 0 & 0 & 0 & 0 & 0 & 0 & & \\
\hline Bare land & 0 & 0 & 0 & 0 & 0 & 0 & 0 & 0 & & \\
\hline Water body & 0 & 0 & 0 & 0 & 0 & 0 & 0 & 0 & & \\
\hline $\begin{array}{l}\text { Year } 2 \\
\text { Total(Ha) }\end{array}$ & 859 & 685 & 1435 & 631 & 23 & 66 & 32 & 3731 & & \\
\hline $\begin{array}{l}\text { Gain }(\mathrm{Ha}) \\
\text { in2018 }\end{array}$ & 616 & 522 & 1107 & 526 & 23 & 66 & 32 & & 2892 & \\
\hline $\begin{array}{l}\text { Gain(\%) in } \\
2018\end{array}$ & 21.3 & 18.0 & 38.3 & 18.2 & 0.8 & 2.3 & 1.1 & & & 100 \\
\hline
\end{tabular}

\subsection{LULC change along slope gradients in Coka watershed}

During 1988-2018, LULC change along slope gradient categorized into cultivated land (cultivated land \& rural settlement, bare land and built up area) and non-cultivated land (forest land, bush land, grass land and water body) (Fig. 5). Cultivated land along slope classes (< $30 \% \&>30 \%$ ) were expanded by $13.4 \& 7.3 \%$ in 1988 to $21.9 \& 16.1 \%$ in 1998 to $22 \& 17.2 \%$ in 2008 and to $22.8 \& 17.6 \%$ in 2018 , respectively. Its annual rate of expansion along stope gradients (<30\% \& >30\%) was $31.9 \& 32.6$ ha/year, 0.2 \& 4.2 ha/year, $3 \& 1.6$ ha/year and $11.7 \& 12.8 \mathrm{ha} /$ year during 1988-1998, 1998-2008, 2008-2018 and 1988-2018, respectively (Fig. 5).

As indicated in Fig. 5, large area coverage of cultivated land was mainly on gentle slopes (<30\%) than steep slope (>30\%) in 1988 but a dramatic increase occurred from 1988 to 1998 on both gentle $(<30 \%)$ and steep (>30\%) slopes might be due to population growth and disbanded durgue arm settlement in the study watershed. Conversely, a less dramatic increase from 2008 to 2018 on both gentle (<30\%) and steep (>30\%) slopes because almost every gentle and steep slopes had already been converted to cultivated land. The areas remained unchanged to cultivated land might be rocky exposure, cliffs, some very marginal bushy area, forest land and grass land around rivers. Under normal situations, steep lands should be covered by forest or used for perennial crops but not for annual crop cultivation. The increasing demand for agriculture activities over decades had brought changes in the LULC system and deforestation of higher slope areas. This steep slope cultivation could result accelerating soil erosion, deforestation, biodiversity loss, climate change and hydrological disturbance in the study watershed.

On the other hand, non-cultivated land on slope classes (<30\% \& >30\%) reduced from 34.8 \& $44.5 \%$ in 1988 to 26.2 \& $35.8 \%$ in 1998 to 25.7 \& $35.1 \%$ in 2008 and $25.5 \& 34 \%$ in 2018 , respectively. Its annual rate of decrement was $32.1 \& 32.4$ ha/year, $1.8 \& 2.6$ ha/year, $0.7 \& 3.9$ ha/year and 11.5 \& 13 ha/year along slope classes (<30\% \& >30\%) during 1988-1998, 1998-2008, 2008-2018 and 1988-2018 p, respectively (Fig. 5). This reveals that non-cultivated land diminished during 1988-2018 periods might be due to expansion of cultivated land to satisfy growing population at the expense of decreasing forest, bush and grass land in the study area. The decrement of noncultivated land could be linked with environmental degradation in terms of deforestation and land degradation.

\subsection{Projection of future LULC area and conversion matrix in Coka watershed}

\section{Cultivated land and rural settlement area (CL \& RS)}


A continuous raise of CL \& RS is projected to be $43.3 \%$ by 2040 and $52.8 \%$ by 2060 (Fig. 6; Table 4). Its rate of increment during 2018-2040, 2040-2060 and 2018-2060 periods will be 8.1, 17.9 and 12.2 ha/year, respectively, which indicates high expansion of CL \& RS for projection periods. During 2018-2060 periods, 360 ha of bush land, 301 ha of grassland and 466 ha of forest land is predicted to be transformed to CL \& RS (Table 5). Among which majority of its gain is from forest land (41.4\%) followed by bush land (31.9\%) with total gain of 1127 ha (53\%). This projection reveals that expansion of CL \& RS might lead to land degradation if inappropriate land use is common. In reverse, 39, 123, 342, 36 and 51 ha of CL \& RS will be converted to bush land, grassland, forest land, built up area and bare land, respectively (Table 5). Its' total loss will be 591 ha (27.8\%) (Table 5).

\section{Forest land}

The projected forest land showed that a decrement trend from 859 ha (23\%) in 2018 to 840 ha (22.5\%) in 2040 and to 728 ha (19.5 \%) in 2060 (Fig. 6; Table 4). The rate of change reveals that forest land will decrease by 0.9, 5.6 and 3.1 ha/year during 2018-2040, 2040-2060 and 2018-2060 periods, respectively (Table 4). As shown in Table 6, it is projected that 65 ha of bush land, 12 ha of grassland and 342 ha of CL \& RS with total of 419 ha (19.7\%) will be transformed to forest land during 2018-2060 periods. Conversely, 51, 466, 10, 4 and 19 ha of forest land will be converted to bush land, CL \& RS, built up area, bare land and water body respectively with total loss of 550 ha (25.9\%) in the same periods which projected decrement of forest could be directly connected with $\mathrm{CO}_{2}$ emission (climate change) that may contribute to environmental degradation in study watershed.

Table 4

The predicted LULC area between 2018 and 2060 in Coka watershed

\begin{tabular}{|c|c|c|c|c|c|c|c|c|c|c|c|c|}
\hline \multirow{3}{*}{ LULC Types } & \multicolumn{6}{|c|}{ Predicted LULC area (2018-2060) } & \multicolumn{6}{|c|}{ Predicted LULC change rate (2018-2060) } \\
\hline & \multicolumn{2}{|l|}{2018} & \multicolumn{2}{|l|}{2040} & \multicolumn{2}{|l|}{2060} & \multicolumn{2}{|c|}{$2018-2040$} & \multicolumn{2}{|c|}{$2040-2060$} & \multicolumn{2}{|c|}{$2018-2060$} \\
\hline & $\mathrm{Ha}$ & $\%$ & $\mathrm{Ha}$ & $\%$ & $\mathrm{Ha}$ & $\%$ & $\mathrm{Ha}$ & $\%$ & $\mathrm{Ha}$ & $\%$ & $\mathrm{Ha}$ & $\%$ \\
\hline Bush land & 685 & 18.3 & 495 & 13.3 & 261 & 7.0 & -8.6 & -27.7 & -11.7 & -47.3 & -10.1 & -61.9 \\
\hline Grass land & 631 & 16.9 & 598 & 16.0 & 470 & 12.6 & -1.5 & -5.2 & -6.4 & -21.4 & -3.8 & -25.5 \\
\hline Forest land & 859 & 23 & 840 & 22.5 & 728 & 19.5 & -0.9 & -2.2 & -5.6 & -13.3 & -3.1 & -15.3 \\
\hline CL \& RS & 1435 & 38.5 & 1614 & 43.3 & 1971 & 52.8 & 8.1 & 12.5 & 17.9 & 22.1 & 12.8 & 37.4 \\
\hline Built Up Area & 23 & 0.6 & 42 & 1.1 & 80 & 2.1 & 0.9 & 82.6 & 1.9 & 90.5 & 1.4 & 247.8 \\
\hline Bare land & 66 & 1.8 & 93 & 2.5 & 139 & 3.7 & 1.2 & 40.9 & 2.3 & 49.5 & 1.7 & 110.6 \\
\hline Waterbody & 32 & 0.9 & 49 & 1.3 & 82 & 2.2 & 0.8 & 53.1 & 1.7 & 67.3 & 1.2 & 156.3 \\
\hline Total & 3730 & 100 & 3731 & 100 & 3731 & 100 & & & & & & \\
\hline
\end{tabular}

\section{Bush land}

As indicated (Fig. 6; Table 4), bush land will be transformed from 18.3\% in 2018 to $13.3 \%$ in 2040 and to $7.0 \%$ in 2060 . Its predicted rate of decrement during 2018-2040, 2040-2060 and overall 2018-2060 is 27.7, 47.3 and 61.9\%, respectively. However, 63 ha of grassland, 51 ha of forest land and 39 ha of CL \& RS will be converted to bush land with total gain of 153 ha (7.2\%). Reversely, among 577 ha ( $27.1 \%)$ total loss of bush land,125 ha to grassland, 65 ha to forest land, 360 ha to CL \& RS, 5 ha to built up area, 6 ha to bare land and 16 ha to water body will be transformed during 2018-2060 (Table 5). This conversion shows that human activities in bush land area are high.

\section{Grassland}

A decrement of grass land is predicted to be observed from 631 ha (16.9\%) in 2018 to 598 ha (16.0\%) in 2040 and to 470 ha (12.6\%) in 2060 (Fig. 6; Table 4). The rate of decreasing pattern between 2018-2040, 2040-2060 and 2018-2060 periods is projected to be by $1.5,6.4$ and 3.8 ha/year, respectively. As indicated in Table 5, transformation of grassland will be 125 ha from bushland and 123 ha from CL \& RS with total gain of 248 ha (11.7\%). In opposite, 63 ha, 12 ha, 301 ha, 6 ha, 12 ha and 15 ha of grass land will be converted to bush land, forest land, CL \& RS, built up area, bare land and water body, respectively, with the total loss of 409 ha (19.2\%) in the mentioned periods. 301 ha (73.6\%) of grass land which is the highest, will be transformed to CL \& RS in projected land map. This reveals that expansion of CL \& RS will be high at the expense of grassland if not protected by rules and regulations for the projected periods in the study watershed. 
Table 5

LULC conversion matrix between 2018 and 2060 in Coka watershed

\begin{tabular}{|c|c|c|c|c|c|c|c|c|c|c|}
\hline \multirow{2}{*}{$\begin{array}{l}\text { LULC in } \\
2018(\mathrm{Ha})\end{array}$} & \multicolumn{10}{|c|}{ LULC conversion matrix in Coka watershed in $2060(\mathrm{Ha})$} \\
\hline & $\begin{array}{l}\text { Bush } \\
\text { land }\end{array}$ & $\begin{array}{l}\text { Grass } \\
\text { land }\end{array}$ & $\begin{array}{l}\text { Forest } \\
\text { land }\end{array}$ & $\begin{array}{l}\mathrm{CL} \\
\& R S\end{array}$ & $\begin{array}{l}\text { Built } \\
\text { Up }\end{array}$ & $\begin{array}{l}\text { Bare } \\
\text { land }\end{array}$ & $\begin{array}{l}\text { Water } \\
\text { body }\end{array}$ & $\begin{array}{l}\text { Total in } \\
2018\end{array}$ & $\begin{array}{l}\text { Loss } \\
(\mathrm{Ha})\end{array}$ & $\begin{array}{l}\text { Loss (\%) in } \\
2018\end{array}$ \\
\hline Bush land & 108 & 125 & 65 & 360 & 5 & 6 & 16 & 685 & 577 & 27.1 \\
\hline Grass land & 63 & 222 & 12 & 301 & 6 & 12 & 15 & 631 & 409 & 19.2 \\
\hline Forest land & 51 & 0 & 309 & 466 & 10 & 4 & 19 & 859 & 550 & 25.9 \\
\hline CL \& RS & 39 & 123 & 342 & 844 & 36 & 51 & 0 & 1435 & 591 & 27.8 \\
\hline Built Up & 0 & 0 & 0 & 0 & 23 & 0 & 0 & 23 & 0 & 0 \\
\hline Bare land & 0 & 0 & 0 & 0 & 0 & 66 & 0 & 66 & 0 & 0 \\
\hline Waterbody & 0 & 0 & 0 & 0 & 0 & 0 & 32 & 32 & 0 & 0 \\
\hline Total in2060 & 261 & 470 & 728 & 1971 & 80 & 139 & 82 & 3731 & 2127 & 100 \\
\hline Gain in 2060 & 153 & 248 & 419 & 1127 & 57 & 73 & 50 & & & \\
\hline Gain(\%) & 7.2 & 11.7 & 19.7 & 53.0 & 2.7 & 3.4 & 2.3 & & & \\
\hline
\end{tabular}

\section{Built up area}

Built up area will increase from 23 ha (0.6\%) in 2018 to 42 ha (1.1\%) in 2040 and to 80 ha (2.1\%) in 2060 by rate of increment $0.9,1.9$ and 1.4 ha/year during 2018-2040, 2040-2060 and 2018-2060, respectively (Fig. 6; Table 4). During 2018-2060, 5 ha of bush land, 6 ha of grassland, 10 ha of forest land and 36 ha of CL \& RS with total of 57 ha (2.7\%) will be transformed to built up area (Table 5). This divulges that expansion of built up area (urbanization) will be occurred at the expense of other land use types during $2018-260$.

\section{Bare land}

It is predicted that bare land will increase from 66 ha in 2018 to 93 ha in 2040 and to 139 ha in 2060 (Fig. 6; Table 4). The rate of increment during 2018-2040, 2040-2060 and 2018-2060 periods will be 1.2, 2.3 and 1.7 ha/year, respectively. As shown in Table 5, 6 ha of bush land, 12 ha of grassland, 4 ha of forest land and 51 ha of CL \& RS with total of 73 ha (3.4\%) will be transformed to bare land. This projection indicates that expansion of bare land will be happened during 2018-2060 which could be associated to land degradation, low crop productivity, climate change and soil fertility deterioration if management intervention is slow.

\section{Water body}

An increment in water body from 32 ha (0.9\%) in 2018 to 49 ha (1.3\%) in 2040 and to 82 ha (2.2\%) in 2060 with changing rate of $0.8,1.7$ and 1.2 ha/year during 2018-2040, 2040-2060 and 2018-2060 periods respectively, is projected (Fig. 6; Table 4). Thus, during the mentioned periods, 50 ha (2.3\%) of other land categories will be changed to water body. In this regard, 16 ha of bush land, 15 ha of grassland and 19 ha of forest land will be transformed to water body (Table 5). This finding divulges that expansion of water body will be happened during 2018-2060 periods which could be opportunity for local community to use water for crop irrigation and harvest fishes and also it could cause for biodiversity loss due to displacement of wild animals from their homestead and loss of medicinal and indigenous plants in the Coka watershed.

\subsection{Accuracy assessments}

The accuracy and kappa statistics result of the three decades classified images are presented in Table 2 . An overall accuracy of $87,85,88$ and $91 \%$ were obtained for the classified images of 1988, 1998, 2008 and 2018 years, respectively (Table 7). Producer's accuracy (PA) of the individual types of the four classified maps varied from 77\% (bush land) in 2008 to 100\% (water body) in 2018 and User's accuracy (UA) was highest for the water body (95\%) in 2018 and lowest for the grassland (79\%) in 2008. A kappa coefficient of $0.84,0.83,0.87$ and 0.89 were resulted for 1988, 1998, 2008 and 2018 LULC maps, respectively. Hence, the results indicated strong agreement of the classified image with ground truths.

\subsection{Discussion}


Generally, during 1988-2018 periods, cultivated and rural settlement land, built up area, bare land and water body have revealed an increment but forest land, grassland and bush land have shown a decrement in size in the Coka watershed (Table 2). According to Kindu et al. (2013) and Solomon et al. (2018) accuracy rating, accuracy of the study watershed result is reasonably high range of LULC changes classification accuracies with ground truth. The finding of this study is consistent with other studies reported by Temesgen et al. (2014) in dera District of north westen Ethiopia; Solomon et al. (2014) in Birr and Upper-Didesa watershed of Blue Nile basin, Gessesse and Kleman (2007) in South Central Rift Valley Region of Ehiopia; Rientjes et al. (2011) in Upper Gilgel Abbay catchment of Blue Nile basin; Gebremicael et al. (2013) in Blue Nile basin; where the cultivated and rural settlement land, built up area and bare land dramatically increased whereas forest land, bush land and grass land were shrinking in the Coka watershed. Ebrahium and Mohamed (2017) in Geleda catchment and Solomon et al. (2014) in Blue Nile basin also reported the growth of cultivated land at the reduction of forest cover in the respective study periods. In the same way, grassland declined by 32\% between 1985-2010 periods in Metema watershed, Ethiopia (Binyam et al., 2015). Similarly, forest land showed decrement in the present study area which was agreed with the result of kindu et al. (2013) and Girmay et al. (2010) who reported a fast decline of forest cover and increment of other land covers in Munessa-shashemene and Gum selassa, respectively.

The projected LULC change showed that cultivated and rural settlement land, built up area, bare land and water body will be increased but forest land, grass land and bush land will be decreased in different proportions in Coka watershed (Table 4). On top of this, Temesgen et al. (2017) reported that projected cultivated land and built up area will be increased during 2030-2045 at the expense of forest land, bush land and grass land, Ethiopia. As reported by Sinan et al. (2014), bare land will be raised in 2030 by $31.75 \%$ in Tikrit, Iraq.

The conversions of one LULC category to another during 1988-2018 and projected during 2018-2060 period are presented in Tables 3 \& 5, respectively. Transformations of LULC from one category to another are clearly occurred in the Coka watershed at the specified three periods and projected four periods. Generally, during the three periods the transformations of cultivated and rural settlement land from bush land and grass land are higher than any other categories conversions in Coka watershed. In agreement with this study, Hailemariam et al. (2016) showed that, 92, 577 ha of bush land converted into cultivated land between 1985 and 2016 in the Bale Mountain Eco-Region of Ethiopia. Similarly, cultivated land, built up area and bare land increased by $19.9 \%, 35.1 \%$ and $28.6 \%$ in expense of forest land, grassland and bush land during 1973-2007 periods in the Modjo watershed (Berhan et al., 2014) and by 12.5\%, 1677.8\% and 50\% during 1957-2017 in Wanka watershed (Wondwosen et al. 2018). However, such trend of forest land, grass land and bush land loss is not uniform throughout the country indicating land use and land cover dynamics are socioeconomic, culture and site dependent (Girmay et al., 2010). The projected cultivated land, built up area and water body will be expanded at the expense of forest land, grass land and bush land in the Coka watershed which is in agreement findings reported by Temesgen et al. (2017) in Ethiopia and Muhammad and Han (2019) in Indonesia.

The expansion of cultivated land over non cultivated land observed in past and present land use even into the marginal and steep slope land of Coka watershed during 1988-2018 period (Fig. 5). There was mismanagement of natural resource such as overgrazing, deforestation and expansion of cultivated land into the marginal land as well as steep slope for the survival of their livelihoods which is similar with reported by (Minale and Rao 2012a, b; Amare 2013; Asres et al. 2016). Despite the expansion of cultivation from sloping into steeper slope with inappropriate soil and water conservation measures, crop production is still lagging behind by $2.67 \%$ annual population growth rate (Asres et al. 2016). Population growth is one of major driving force for land use and land cover change in the Coka watershed. Similarly, Population growth exerts massive pressure on land use and land cover change, agricultural productivity, and the use of ecosystem in Ethiopia (Minale and Rao 2011). Almost all steep slopes, even that $>60 \%$ are under cultivation (Fig. 5). No special protection mechanisms exist except some traditional ditches, which in most cases aggravate runoff, especially on steep slopes. Because of these processes, the area is heavily threatened by land degradation. Amare and Rao (2012) have shown that in Ethiopian highlands, rural poor households have caused land degradation.

According to FGD and KII respondents, major driving forces for LULC changes in Coka watershed are population growth, expansion of cultivated land, fuel and construction material need, socioeconomic factors, police and instructional changes and expansion of built up area (urbanization) which is reliable with the findings reported by (Yesuf et al. 2015 and Warra, et al. 2013). This may become with very severe environmental degradation in the Coka watershed in near future. Communities have been under food security problem for many decades and have tried to adapt to changing conditions. However, since their efforts have not been systematically supported by stable institutions and policies, the farming system currently appears to be in a very critical condition.

\section{Conclusion}

Considerable amount of land use and land cover (LULC) transformation during the periods (1988-2018) has occurred in Coka watershed and conversion from 2018 to 2060 periods is projected. The implications of conversion of one land use type to the other depend on its positive or negative impact on our environment. The spatial and temporal analysis of LULC change of Coka watershed clearly indicates the

Page 12/19 
prevalence of serious environmental degradation and related problems the area will face in the near future. The changes have been dramatic for the traditional agricultural system, and the impacts are now highly visible.

During 1988-2018 periods, Cultivated land and rural settlement (CL \& RS), built up area, bare land and water body were increased but forest land, grass land and bush land were decreased in size in the study area. It is also similar that the pattern of increasing and decreasing for projected LULC change during 2040-2060 periods. Population growth, fuel and construction material need, expansion of cultivated land, socioeconomic factors, police and institutional changes and urbanization are major driving forces of LULC changes in study area. The consequences of LULC changes are presence of biodiversity loss, soil erosion, scarcity of firewood, climate change and hydrologic disturbance and land degradation in the Coka watershed.

In general, it can be concluded that LULC change processes and associated problems observed in the study watershed have regional, national, and international implications. The present study is a useful tool for analysis of environmental sensitivity on a watershed scale and the identification of hotspots of LULC change which may depend on social, economic and environmental condition of study watershed. Thus, detailed investigations of household mechanisms for adaptation of the changes observed are essential for future action and a multilevel stakeholder approach to sustainable land management is needed. Therefore, existing biophysical, socio-economic, land policy, and institution strategies should be given high priority, at least to prevent existing potential from further deteriorating.

\section{Declarations}

\section{Credit authorship contribution statement}

Tadele Buraka Bushasha: Conceptualization, Data curation, Formal analysis, Writing - original draft. Eyasu Elias: Supervision, Visualization, Investigation, review \& editing.

\section{Declaration of competing interest}

The authors declare that they have no known competing financial interests or personal relationships that could have appeared to influence the work reported in this paper.

\section{Acknowledgments}

We would like to thank Hawassa university and southern state regional soil laboratory for conducting the soil analysis and the Center of Environmental science at Addis Ababa University and Wachemo university for providing financial support. Finally, the authors would also like to express their gratitude to the editor and anonymous reviewers for their comments, which greatly improved the scientific quality of this work.

\section{References}

1. Abate, S. 2011. Evaluating the land use and land cover dynamics in Borena Woreda of South Wollo highlands, Ethiopia. J.Sustain.Dev.Afr.13(1):87-105

2. Agidew AA., Singh KN., 2017. The implications of land use and land cover changes for rural household food insecurity in the Northeastern highlands of Ethiopia: the case of the Teleyayen subwatershed. Agric Food Secur 6(56):1-14

3. Assefa, E., \& Bork, H.-R., 2016. Dynamics and driving forces of agricultural landscapes in Southern Ethiopia-a case study of the Chencha and Arbaminch areas. Journal of Land Use Science, 11, 278-293.

4. Araya A., Stroosnijder L. 2011. Assessing drought risk and irrigation need in northern Ethiopia. Agricultural and Forest Meteorology, 151 (4) (2011), pp. 425-436

5. Asmamaw, L.B., Mohammed, A.A., Lulseged, T.D., 2011. Land use/cover dynamics and their effects in the Gerado catchment, northeastern Ethiopia. Int. J. Environ. Stud. 68, 883-900.

6. Bai, Z. G., Dent, D. L., Olsson, L., and Schaepman, M. E.2008. Global assessment of land degradation and improvement, identification by remote sensing, Report No. 12, ISRIC, Wageningen,70 pp.

7. Berhan G., Woldeamlak B. and Achim B., 2014. "Model-based characterization and monitoring of runoff and soil erosion in response to land use/land cover changes in the Modjo watershed, Ethiopia." Land degradation and Development, In press DOI: 10.1002/Idr.2276.

8. Binyam A., Efrem G., Zewdu E., and Habtemariam K., 2015. Land Use and Land Cover Changes and Associated Driving Forces in North Western Lowlands of Ethiopia. International Research Journal of Agricultural Science and Soil Science (ISSN: 2251-0044) Vol. 5(1) pp. 28-44.

Page 13/19 
9. Central Statistical Agency of Ethiopia(CSA), 2007, 2018 \& 2019. Population and housing census of Atlas of Ethiopia. Central statistical Agency of Ethiopia, Addis Ababa, Ethiopia.

10. Clark Labs, 2012. Idrisi Selva help system. Clark University, Worcester

11. Congalton, R. 1991. A review of assessing the accuracy of classifications of Remotely sensed data. Remote Sens Environ 37:35-46

12. Congalton, RG., 2005. Thematic and positional accuracy assessment of digital remotely sensed data. Proceedings of the seventh annual forest inventory and analysis symposium. Pp.149-154

13. Congalton, RG., Green, K., 1999. Assessing the accuracy of remotely sensed data: Principles and practices. Lewis Publishers, Boca.Raton,p137

14. Efrem G., 2010. Land-use and land-cover dynamics and rural livelihood perspectives, in the semi-arid areas of Central Rift Valley of Ethiopia. Dissertation, Swedish University of Agricultural Sciences.

15. FAO, 2010. Global forest resource assessment. In: FAO Forestry paper 163, Main Report, Rome, Italy.

16. Gebrehiwot, S.G., Bewket, W., Gärdenäs, A.I., Bishop, K., 2014. Forest cover change over four decades in the Blue Nile Basin, Ethiopia: comparison of three watersheds. Reg. Environ. Change 14, 253-266.

17. Gebremicael, TG., Mohamed, YA., Betrie, GD., vaniderZaag, P., Teferi E. 2013. Trend analysis of runoff and sediment fuxes in the Upper Blue Nile basin: a Combined analysis of statistical tests, physically-based models and land Use maps. J. Hydrol. 482:57-68.

18. Gebrekidan, Amare and Habtamu, 2014. Land use and land cover change in Ameleke Watershed, South Ethiopia.

19. Girmay, G., Singh, B.R., Dick, $\varnothing ., 2010$. Land-use changes and their impacts on soil degradation and surface runoff of two catchments of northern Ethiopia. Acta Agric. Scand. Sect. B Soil Plant Sci. 60, 211-226.

20. Gong, J., Yang, J., \& Tang, W. (2015). Spatially explicit landscape-level ecological risks induced by land use and land cover change in a national ecologically representative region in China. International journal of environmental research and public health.

21. Hagos G., 2014. Land Use-Land Cover dynamics of Huluka watershed, Central Rift Valley, Ethiopia. International Soil and Water Conservation Research, Vol. 2, No. 4, 2014.

22. Hurni, H., Kebede, T., Gete, Z., 2005. The implications of changes in population, Land use, and land management for surface runoff in the Upper Nile Basin area of Ethiopia. Mt. Res. Dev.25(2):147-154

23. IFAD, 2011. Rural poverty Report: New realities new Challenges: New opportunities for tomorrow's generation IFAD (Ed.), Rural poverty report (2011), p. 322 (Rome, Italy

24. Kebrom Tekle and Hedlund, L., 2000. "Land cover changes between 1958 and 1995 in Kalu District, Southern Wello, Ethiopia." Mountain Research and Development, 20: 42-51

25. Kindu, D.F., Schneider, T., teketay, D., Knoke, T., 2013. Land use/land cover change analysis using object based classified approach in munessa-sheshemene landscape of the Ethiopian Hihglands. Remote sens. 5, 2411-2435.

26. Lambin, E.F., Meyfroidt, p., 2011. Global land use change, economic globalization, and the looming land scarcity. Proce. Natl. Acad.Sci.UsA 108, 3465-3472.

27. Li, A., Lei, G., Cao, X., Zhao, W., Deng, W., Koirala, H.L., 2017. Land cover change and its driving forces in Nepal since 1990. In: Li, A., Deng, W., Zhao, W. (Eds.), Land Cover Change and Its Eco-environmental Responses in Nepal. Springer, Singapore,Singapore, pp. 4165.

28. Meshesha, D.T., Tsunekawa, A., Tsubo, M., Ali, S.A., Haregeweyn, N., 2014. Land use changes and its socio-environmental impact in Eastern Ethiopia's highland. Reg.Enviro.Change 14, 757-768.

29. Monserud, RA. 1990. Methods for comparing global vegetation maps, Report WP-90-40. ASA, Laxenburg

30. Mosammam, H., Nia, J., Khani, H., Teymouri, A., Kazem, M., 2016. Monitoring land use change and measuring urban sprawl based on its spatial forms: the case of Qomicity. Egypt.J.Remote. Sens.Space.Sc.do:10.1016/j.ejrs.2016.08.002

31. Muhammad Hadi Saputra and Han Soo Lee, 2019. Prediction of Land Use and Land Cover Changes for North Sumatra, Indonesia, Artificial-Neural-Network-Based Cellular Automato.

32. Nanda AM., Hajam RA., Hamid A., Ahmed P., 2014. Changes in land use / land-cover dynamics using geospatial techniques: a case study of Vishav Drainage basin. J Geogr Region Plan 7(4):69-77

33. Nyssen, J., Getachew, S. \& Taha, N., 2008. An upland farming system under transformation: Proximate causes of land use change in Bela-Welleh catchment (Wag, Northern Ethiopian Highlands). xxx, 1-8.

34. Rientjes, TH., Haile, AT., Kebede, E, Mannaerts. CM., Habib, E., Steenhuis, TS., 2011. Changes in land cover, rainfall and stream flow in Upper Gilgel Abbay catchment, Blue Nile basin Ethiopia. Hydrol.Earth.Syst.Sci.15:1979-1989 
35. Schulz, JJ., Cayuela, L., Echeverria, C., Salas, J., Rey Benayas, JM., 2010. Monitoring land cover change of the dryland forest landscape of Central Chile (1975-2008). Appl.Geogr.30:436-447.

36. Sinan J.H., Helmi Z. and Mustafa D., 2014. Modelling LULC for the period 2010-2030 using GIS and remote sensing: - A case study of Tikrit, Iraq.

37. Solomon, G., Woldeamlak, B., Gardenas, A., Bishop, K., 2014. Forest cover change over four decades in the Blue Nile Basin, Ethiopia: comparis on of three watersheds. Reg. Environ. Change. 14:253-266

38. Teferi, E., Uhlenbrook, S., Bewket, W., Wenninger, J., Simane, B. 2010. The use of remote sensing to quantify wetland loss in the Choke Mountain range, Upper Blue Nile basin, Ethiopia. Hydrol.Earth.Syst.Sci.14:2415-2428

39. Temesgen, G., Amare, B., Abraham, M., 2014. Evaluation of land use/land cover changes and land degradation in Dera District, Ethiopia: GIS and remote sensing based analysis. Int J. Sci. Res. Environ. Sci. 2(6):199-208.

40. Temesgen, G., Tafa, T., Mekuria, A. and Abeyou W., 2017. Evaluation and prediction of land use/land cover changes in the Andassa watershed, Blue Nile Basin, Ethiopia.

41. Tsehaye, G., Mohammed, A., 2013. Land use/land cover dynamics and their driving forces in the Hirmi watershed and its adjacent agroecosystem, highlands of Northern Ethiopia. J Land Use Sci. https://doi.org/10.1080/17474 23X.2013.845614

42. USGS, 2018. Landsat Collection 1 Level 1 Product Definition In: Survey, D.o.t.I.U.S.G.(Ed.). USGS, Sioux Falls, South Dakota, USA.

43. Warra, H. H., Mohammed, A. A., Melanie D. Nicolau, 2013. Spatio-temporal impact of socio-economic practices on land use/ land cover in the Kasso Catchment, Bale

44. Wang, SQ., Zheng, XQ., Zang, XB., 2012. Accuracy assessments of land use change simulation based on Markov-cellular automata model. Procedia.Environ.Sci.13:1238-1245

45. Woldeamlak B., Solomon, A., 2013. Land-use and land-cover change and its environmental implications in a tropical highland watershed, Ethiopia. Int J Environ Stud 70(1):126-139

46. Wondie, M., Schneider, W., Melesse, A., Teketay, D., 2011. Spatial and temporal land cover changes in the simen mountains national parks, a world hertige site in Northestern Ethiopia. Remote sens. 3,752-766.

47. Worku, TS., Tripath, SK., Khare, D., 2016. Analyses of land use and land cover change dynamics using GIS and remote sensing during 1984 and 2015 in the Beressa watershed Northern Central highland of Ethiopia. Model Earth Syst Environ 2:168

48. Worqlul, A.W., Collick, A.S., Rossiter, D.G., Langan, S., Steenhuis, T.S., 2015. Assessment of surface water irrigation potential in the Ethiopian highlands: The Lake Tana Basin Catena, 129 (2015), pp. 76-85

49. Wubie, MA., Assen M., Nicolau MD., 2016. Patterns, causes and consequences of land use/cover dynamics in the Gumara watershed of lake Tana basin, Northwestern Ethiopia. Environ Syst Res 5:8. https ://doi.org/10.1186/s4006 8-016-0058-1

50. Wu, X., Tang, Z., Cui, H., Fang, J., 2007. Land cover dynamics of different topographic conditions in Beijing, China. Front. Biol. 2, 463473.

51. Yesuf Hassen M., Mohammed Assen, Melesse Assefa M. and Alamirew Tena. 2015. Detecting land use/land cover changes in the Lake Hayq (Ethiopia) drainage basin, 1957-2007

52. Yohannes, H., Mohammed, A., \& Elias, E., 2017. Land Use/Land Cover Dynamics and Its Impact on Biodiversity Resources in the Abijata Shalla National Park, Central Rift Valley Lakes Region, Ethiopia. Environ Sci Ind J, 13, 152.

\section{Tables}

Tables 6 and 7 are not available with this version.

\section{Figures}



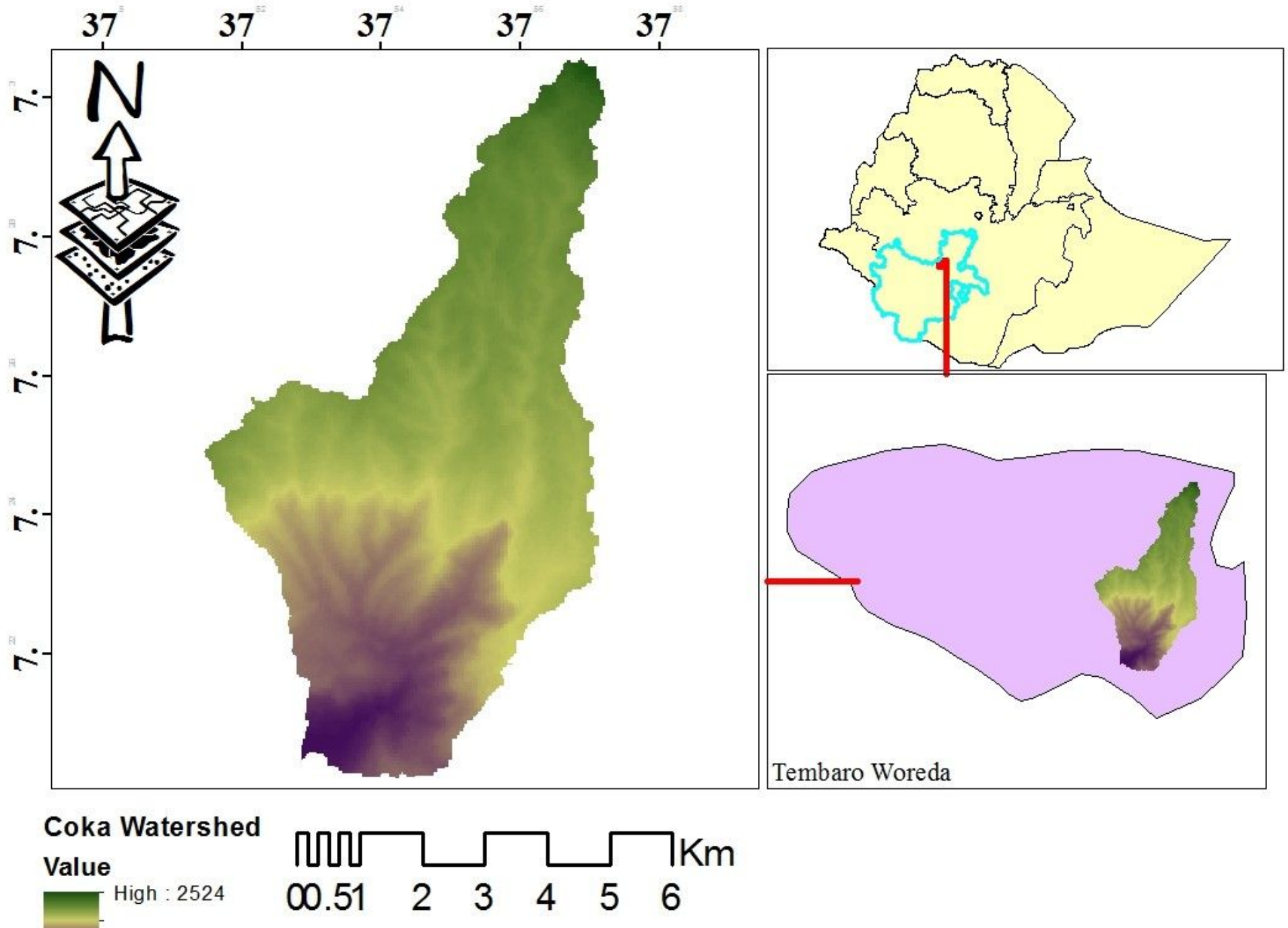

Low : 772

Disclaimer: This map was produced based on shapefiles obtained from gadm.org.

Figure 1

Map of the study watreshed 


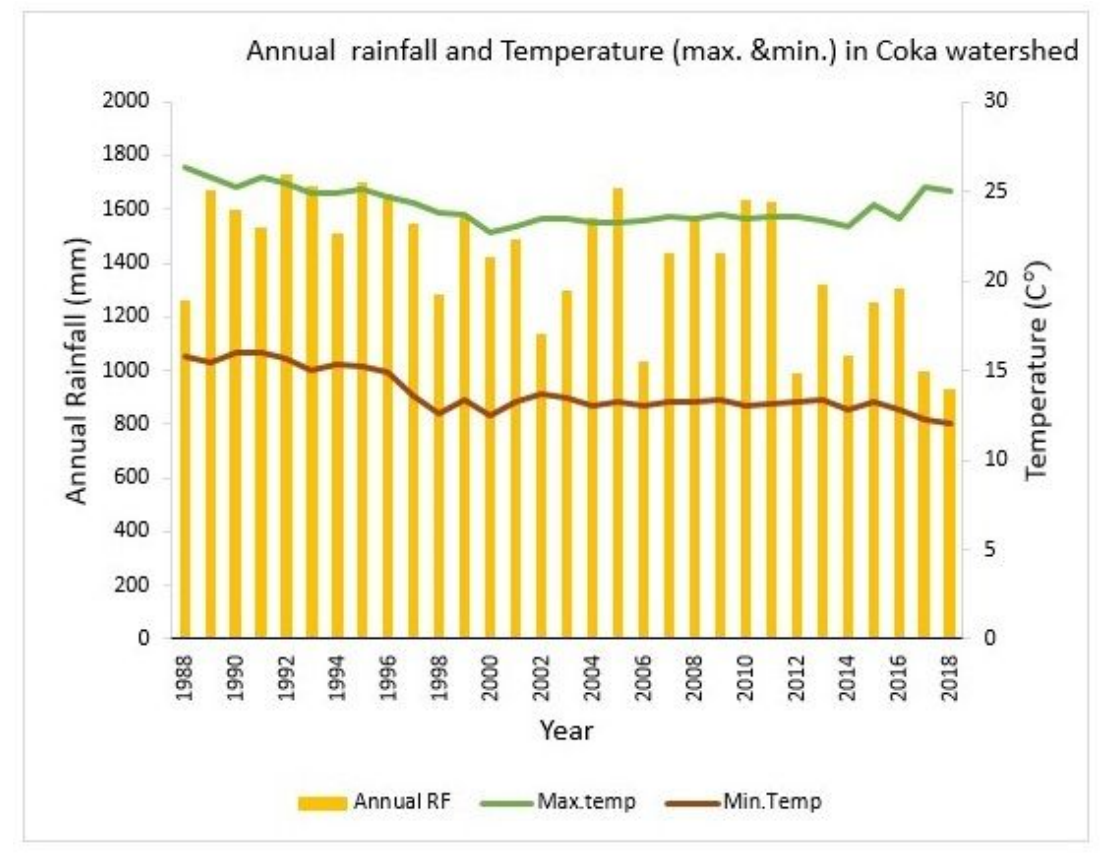

Figure 2

The mean annual rainfall and temperature in Coka watershed

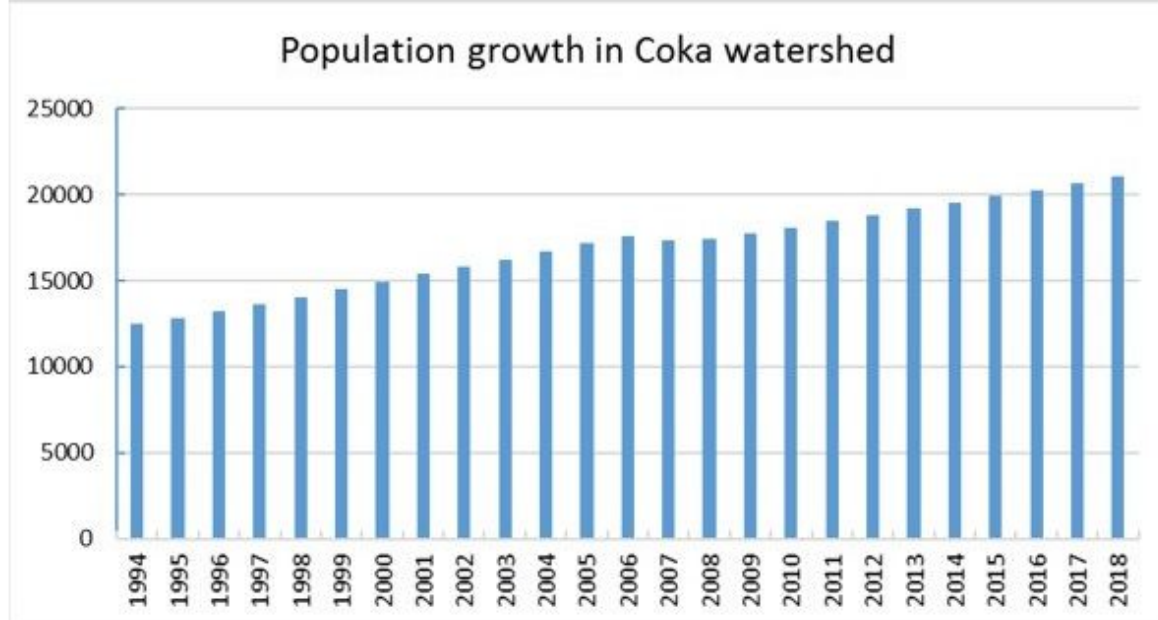

\section{Figure 3}

Population growth in Coka watershed (Source: Own analysis on raw data from CSA, 2019) 


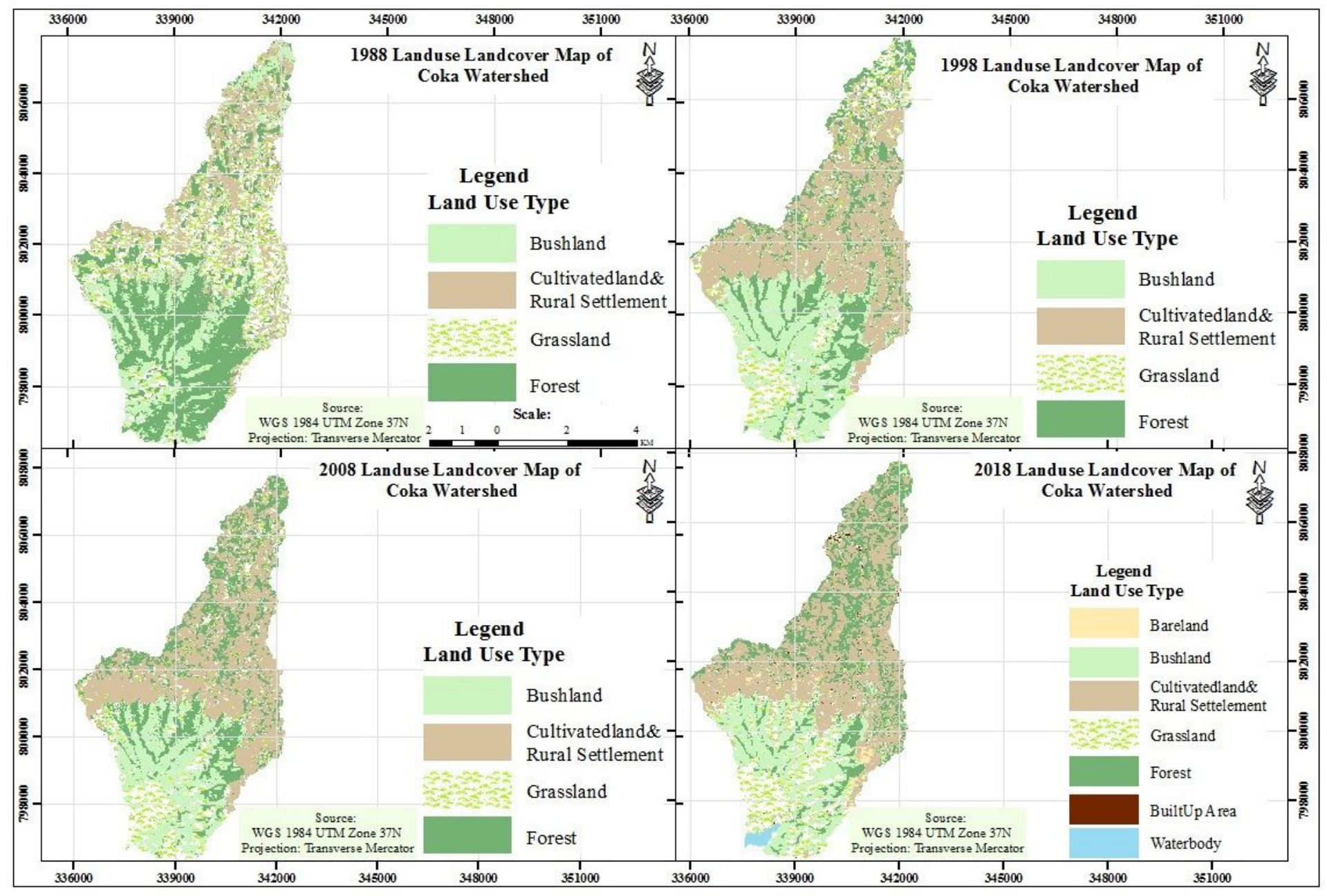

Figure 4

LULC change map in Coka watershed during 1988-2018

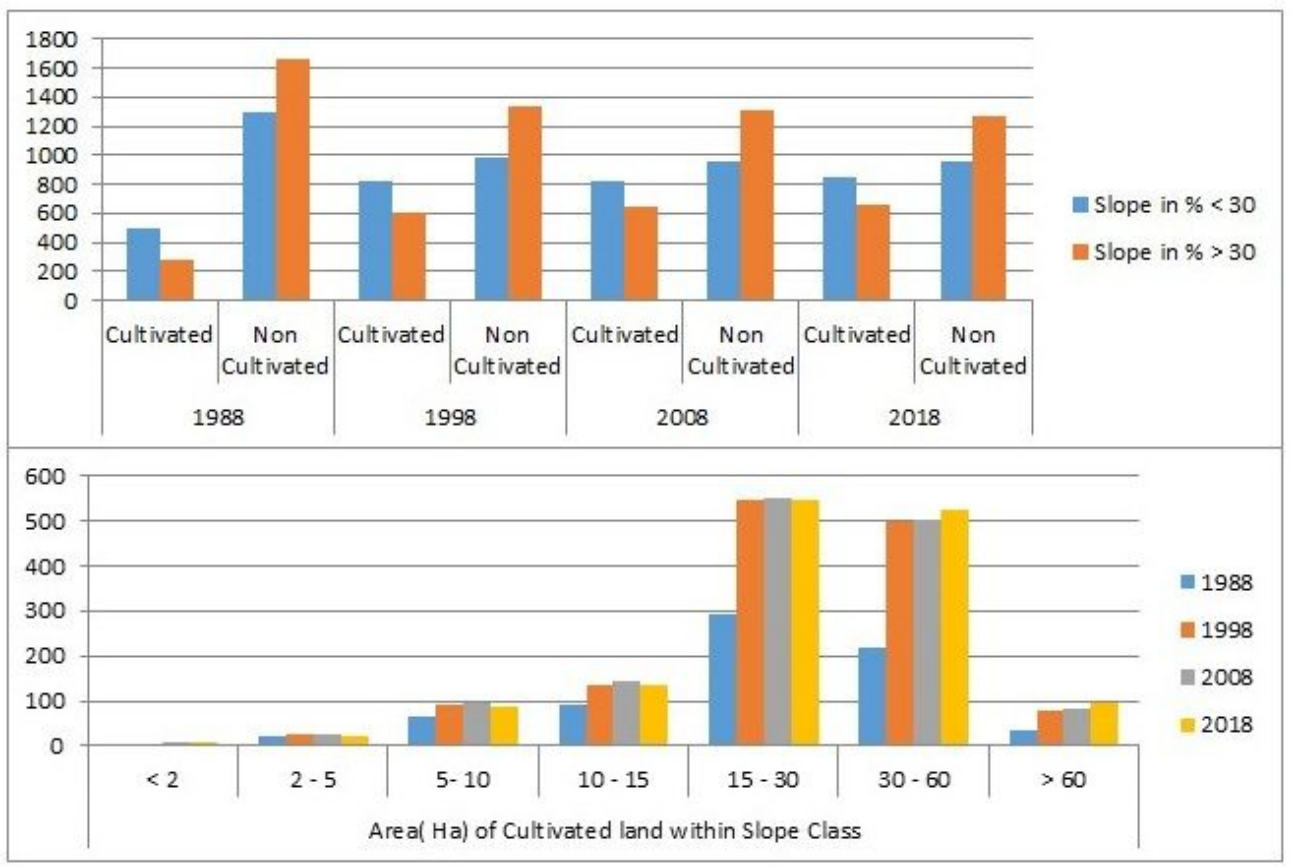

Figure 5 


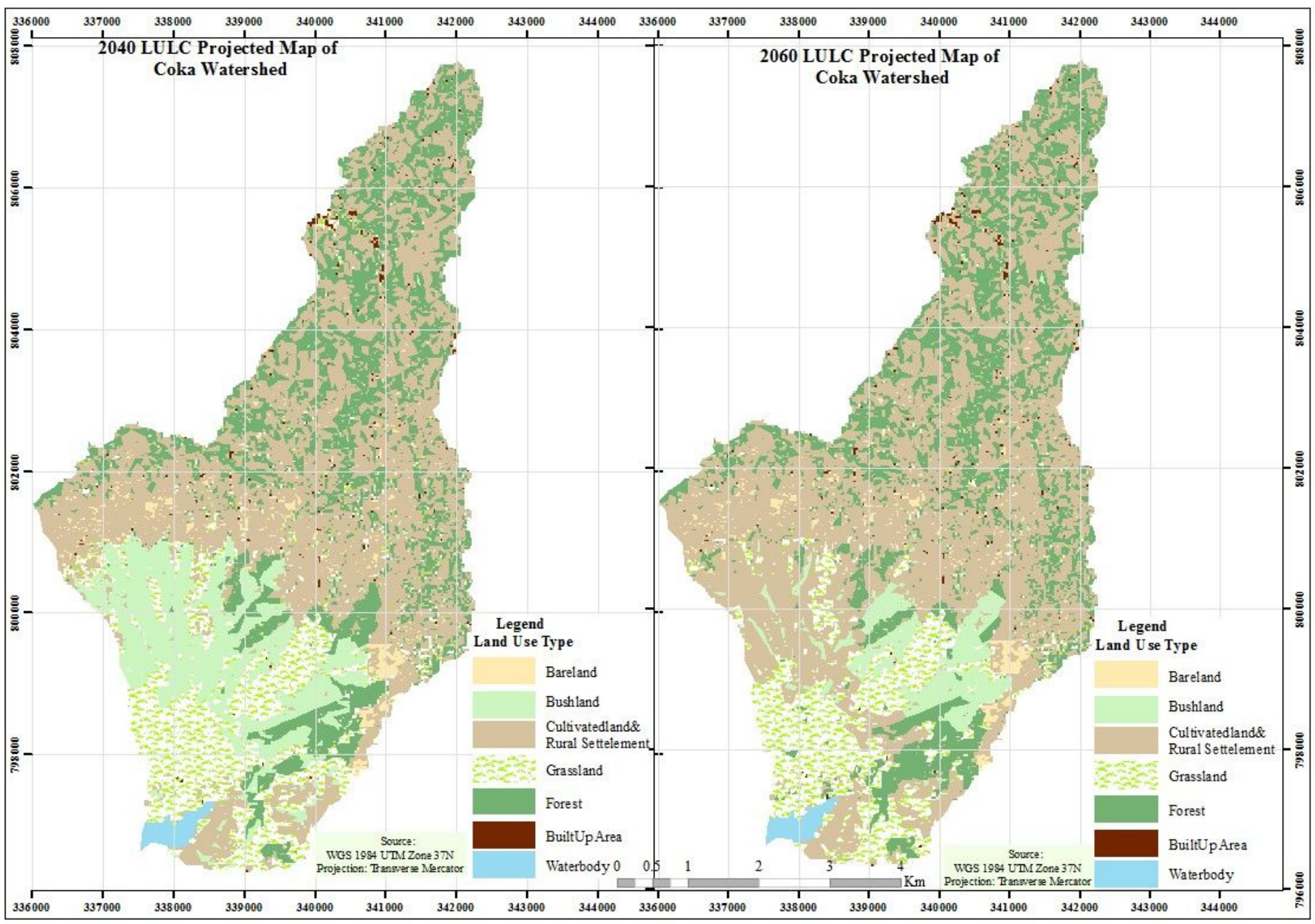

Figure 6

Projected LULC change map in Coka watershed during 2040 and 2060 